\title{
Environmental factors on seed germination and seedling emergence of Phleum paniculatum Huds.
}

\author{
Han $\mathrm{Wu}^{1}$, Pei Zhang ${ }^{1}$, Guoqi Chen ${ }^{1}$, Lang Pan ${ }^{1}$, Jun Li ${ }^{1}$, and Liyao Dong ${ }^{1^{*}}$ \\ ${ }^{1}$ Nanjing Agricultural University, College of Plant Protection, Nanjing 210095, China. "Corresponding author (dly@njau.edu.cn).
}

Received: 6 March 2018; Accepted: 13 June 2018; doi:10.4067/S0718-58392018000300370

\begin{abstract}
Phleum paniculatum Huds., commonly known as British timothy, is an increasingly serious weed in wheat field of China. However, the biology of its seed germination and seedling emergence remain unclear. In the present study, the effects of environmental factors on seed germination and seedling emergence of $P$. paniculatum were explored. Phleum paniculatum seeds had a shallow dormancy $(20-30 \mathrm{~d})$ when stored at room temperature $\left(25 \pm 5^{\circ} \mathrm{C}\right)$. Seeds could germinate at constant temperatures between 10 and $25^{\circ} \mathrm{C}$, except for 5 or $30^{\circ} \mathrm{C}$. Light was not essential for seed germination, and $\mathrm{pH}$ values from 4 to $10 \mathrm{did}$ not inhibit germination. Seeds were moderately adaptable to water potential and $\mathrm{NaCl}$ concentration, and germination rates would be decreased $50 \%$ when water potential was $-0.4 \mathrm{MPa}$ or $\mathrm{NaCl}$ concentration was $130 \mathrm{mM}$. Increased soil burial depth decreased the seedling emergence, and no seeds emerged when the burial depth was more than $4 \mathrm{~cm}$. Taken together, our results provide useful information of the germination and emergence of P. paniculatum seed, and strategies such as proper drainage systems managed and deep plowing are recommended to limit its detrimental effects on agricultural production.
\end{abstract}

Key words: Burial depth, dormancy, light, osmotic potential, salt, temperature.

\section{INTRODUCTION}

Phleum paniculatum Huds., known as British timothy, widely distributed along the Yangtze River, and throughout several provinces including Shanxi, Shaanxi, and Gansu in China as well as in other regions of temperate Eurasia (www.efloras. org). As a short winter annual grass, the life cycle of P. paniculatum coincides with that of winter wheat (Triticum aestivum L.) and oilseed rape (Brassica napus L.) in China (Flora of China; FOC, 2006). Phleum paniculatum frequently thrive on riversides, field margins, and roadsides. Nevertheless, in the recent years, some researchers reported that $P$. paniculatum occurred in wheat fields and even became one of the dominant malignant weeds in Shanxi Province (Gao et al., 2011). Jin et al. (2009) reported that in Zhouzhi county of China, difenzoquat and fenoxaprop could not effectively control $P$. paniculatum. According to our field observations, $P$. paniculatum developed into secondary malignant weeds in wheat fields at the Yangtze River downstream areas. Phleum paniculatum seeds are tawny, obovate, and about $1 \mathrm{~mm}$ long and $0.2 \mathrm{~mm}$ wide (Flora of China; FOC, 2006). Phleum paniculatum commonly produce 1500 to 2900 seeds per plant and seed is quite small, with a thousand-seed weight of only 0.17 to $0.23 \mathrm{~g}$, which can be dispersed by water, wind or farm operation in the fields because of its light weight (Wu personal observation). Moreover, this grass weed could serve as a host for Northern cereal mosaic virus (Ruan et al., 1982) and cereal cyst nematode (Heterodera avenae Wollenweber) (Zhao et al., 2013). Therefore, as a new problematical weed and host of pests in wheat fields, a better understanding of $P$. paniculatum is essential for developing effective management strategies against it.

Seed germination and seedling emergence are the initial steps for weed population establishment, which are influenced by numerous environmental factors, such as temperature, water, light, and seed burial depth (Singh et al., 2012; Javaid and 
Tanveer, 2014). To date, biology on seed germination and seedling emergence of P. paniculatum has not been reported. Here, we conducted a serial of experiments on the dormancy, germination and emergence of this weed species. The objective of this research was to increase our understanding of the effects of temperature, light, $\mathrm{pH}$, salt stress, osmotic stress, and burial depth on seed germination and emergence of $P$. paniculatum and find recommend effective strategies for its control in winter wheat.

\section{MATERIALS AND METHODS}

Phleum paniculatum seed of each individual sample were collected and combined from several fallow fields in Suining county $\left(34^{\circ} 01^{\prime} 0.86^{\prime} \mathrm{N}, 117^{\circ} 53^{\prime} 13.95^{\prime} \mathrm{E}\right)$, China, in May 2017. The climate in Suining County is temperate monsoonal, with a mean annual temperature of $14{ }^{\circ} \mathrm{C}$ and annual precipitation of $991 \mathrm{~mm}$ (National Meteorological Information Center, http://www.nmic.cn/en/). All seeds were cleaned and stored in paper bags at room temperature $\left(25 \pm 5^{\circ} \mathrm{C}\right)$ until used, except a portion of the seeds that were stored at $4{ }^{\circ} \mathrm{C}$ for a seed dormancy experiment.

Seed germination experiments were conducted at Nanjing Agricultural University $\left(32^{\circ} 02^{\prime} 3^{\prime \prime} \mathrm{N}, 118^{\circ} 50^{\prime} 6^{\prime \prime} \mathrm{E}\right)$. In each germination trial described below, 25 seeds of $P$. paniculatum were placed in 9-cm glass petri dishes containing two pieces of filter paper moistened with $5 \mathrm{~mL}$ distilled water $(\mathrm{pH} \mathrm{6.8)}$ ) or with a treatment solution. Dishes were sealed with Parafilm and placed in an incubator with $12 \mathrm{~h}$ of white fluorescent light $\left(140 \mu \mathrm{mol} \mathrm{m}^{-2} \mathrm{~s}^{-1}\right.$ photosynthetic photon flux density) and a photoperiod of $12: 12 \mathrm{~h}$ with $20^{\circ} \mathrm{C} / 10^{\circ} \mathrm{C}$ light/darkness temperatures (unless stated otherwise). Seeds were considered to have germinated when the coleoptile was visible (about $2 \mathrm{~mm}$ in length). Percent germination was determined $15 \mathrm{~d}$ after sowing (Rao et al., 2008; Wu et al., 2016; Du et al., 2017). All experiments were conducted in a completely randomized design with four replicates. Each experiment was conducted twice.

To test for seed dormancy of P.paniculatum, germination experiments were conducted at 1, 10,20, and $30 \mathrm{~d}$ after seed were collected (Wu et al., 2015). Portions of the seeds used for the dormancy trial were stored at both $4{ }^{\circ} \mathrm{C}$ and $25 \pm 5{ }^{\circ} \mathrm{C}$ to evaluate the effect of low temperature on dormancy. All other environmental conditions were the same as described in the general germination protocol.

To evaluate the effect of temperature, dishes containing non-dormant $P$. paniculatum seeds were placed in incubators at constant temperatures ranging from $5{ }^{\circ} \mathrm{C}$ to $30^{\circ} \mathrm{C}$ in increments of $5{ }^{\circ} \mathrm{C}$ or with alternating light/darkness temperatures of $30{ }^{\circ} \mathrm{C} / 20^{\circ} \mathrm{C}, 25^{\circ} \mathrm{C} / 15^{\circ} \mathrm{C}, 25^{\circ} \mathrm{C} / 10^{\circ} \mathrm{C}, 20^{\circ} \mathrm{C} / 15^{\circ} \mathrm{C}, 20^{\circ} \mathrm{C} / 10^{\circ} \mathrm{C}, 15{ }^{\circ} \mathrm{C} / 5{ }^{\circ} \mathrm{C}, 10^{\circ} \mathrm{C} / 5^{\circ} \mathrm{C}$. Germination was determined daily beginning $15 \mathrm{~d}$ after seeds were placed in the incubators.

Seed exposed to different periods of light:no light ( $24 / 0 \mathrm{~h}$ dark/light), constant light ( $0 / 24 \mathrm{~h}$ dark/light), or alternating light and dark conditions (12/12 h dark/light), were evaluated to determine the effect of light on seed germination. To completely exclude light, petri dishes were wrapped with two layers of aluminum foil immediately after being placed in petri dishes.

Non-dormant seeds were incubated in buffered solutions at a $\mathrm{pH}$ of $4,5,6,7,8,9$, or 10 to determine if $\mathrm{pH}$ affects seed germination of P. paniculatum (Chachalis and Reddy, 2000; Wu et al., 2016). Seed incubated using distilled water (pH 6.8) was used as a control for this experiment.

To evaluate the effect of osmotic stress, seeds were incubated in aqueous solutions with osmotic potentials of $0,-0.1$, $-0.2,-0.3,-0.35,-0.4,-0.45-0.5,-0.6$, and $-0.7 \mathrm{MPa}$, prepared by dissolving polyethylene glycol (PEG) 6000 (Solarbio, Beijing, China) in distilled water (Michel and Kaufmann, 1973; Javaid and Tanveer, 2014; Wu et al., 2016). Seeds were placed in incubators at a constant temperature of $15^{\circ} \mathrm{C}$ and a $12: 12 \mathrm{~h}$ light:dark cycle.

Effect of salt stress was evaluated in seeds exposed to seven levels of increasing salinity using $5 \mathrm{~mL}$ of $\mathrm{NaCl}$ solutions prepared at concentrations of $0,10,20,40,80,120,160$, or $320 \mathrm{mM} \mathrm{NaCl}$. The solutions were prepared by dissolving 0 , $0.58,1.17,2.34,4.68,7.02,9.35$, or $18.70 \mathrm{~g} \mathrm{NaCl} \mathrm{L}^{-1}$ distilled water (Wu et al., 2016).

Effect of burial depth was evaluated in 50 seeds sown at depths of 0 (soil surface), 0.5, 1, 2, 3, 4, 5, or $6 \mathrm{~cm}$ in plastic pots (15 cm in diameter and $13 \mathrm{~cm}$ in height) with drain holes at the bottom (Wu et al., 2016). The soil media consisted of a 1:1 mixture, by weight, of medium loam soil ( $\mathrm{pH} 8.06$, with $0.67 \%$ organic matter) and organic matter ( $\mathrm{pH} 8.23$, with $40.4 \%$ organic matter). Seedling emergence was recorded when a coleoptile emerged through the soil surface and was determined $21 \mathrm{~d}$ after sowing. 


\section{Statistical analysis}

Germination and emergence rates were reported as the percentage $\pm 95 \%$ confidence interval. A completely randomized design with four replicates was used for all experiments and each experiment was repeated twice. Differences among treatments were examined with ANOVA analysis. There was nonsignificant $(\mathrm{p}>0.05)$ trial-by-treatment interaction for each experiment; therefore, data were pooled for the final analysis. Germination and seedling emergence data were analyzed with SPSS software (version 22.0, SPSS Inc., Chicago, Illinois, USA) using Tukey's test ( $\mathrm{p} \leq 0.05)$.

The germination percentages of $P$. paniculatum at different salt concentrations, or at different osmotic potentials were fitted to a functional three-parameter logistic model using SigmaPlot (version 10.0, Systat Software Inc., San Jose, California, USA) with the following equation (Wu et al., 2015):

$$
G(\%)=G_{\max } /\left[1+\left(x / x_{50}\right)^{g}\right]
$$

where $G(\%)$ represents the total germination $(\%)$ for the $\mathrm{NaCl}$ concentration, or osmotic potential $x$; $G_{\text {max }}$ is the maximum germination (\%); $x_{50}$ is $\mathrm{NaCl}$ concentration or osmotic potential for $50 \%$ of the maximum germination; and $g$ indicates the slope.

The seedling emergence (\%) obtained at different burial depths was fitted to a sigmoidal decay curve (Eslami, 2011) using SigmaPlot with the following equation:

$$
E(\%)=E_{\max }\left\{1+\exp \left[-E_{\text {rate }}\left(x-x_{50}\right)\right]\right\}
$$

where $E$ denotes the total seedling emergence (\%) at burial depth $x, E_{\text {max }}$ is the maximum seedling emergence $(\%), x_{50}$ is the depth with $50 \%$ of maximum seedling emergence, and $E_{\text {rate }}$ indicates the slope.

\section{RESULTS}

\section{Seed dormancy}

Whether stored at $4{ }^{\circ} \mathrm{C}$ nor at room temperature $\left(25 \pm 5{ }^{\circ} \mathrm{C}\right)$, did not germinate when tested immediately after being harvested (Figure 1). The percent germination for seed stored at room temperature increased rapidly when tested 10,20 , and $30 \mathrm{~d}$ after collection. A remarkable increase in germination was observed at $20 \mathrm{~d}$ after collection $(76 \pm 18.7 \%)$, and germination rate exceeded $90 \%$ at $30 \mathrm{~d}$ after collection. In contrast, germination was almost completely inhibited when seed were stored at $4{ }^{\circ} \mathrm{C}$, reaching only $12.2 \pm 3 \%$ at $30 \mathrm{~d}$ after collection. These results indicate that P.paniculatum seeds has a shallow dormancy $(20-30 \mathrm{~d})$ when stored at room temperature $\left(25 \pm 5^{\circ} \mathrm{C}\right)$, while a low storage temperature, such as $4{ }^{\circ} \mathrm{C}$, maintained seed dormancy.

Figure 1. Germination of Phleum paniculatum sown at 1, 10, 20, $30 \mathrm{~d}$ after storage. Seeds were incubated at $20^{\circ} \mathrm{C} / 10{ }^{\circ} \mathrm{C}$ with a $12: 12 \mathrm{~h}$ photoperiod for $30 \mathrm{~d}$. Error bars represent $95 \%$ confidence interval of the means.

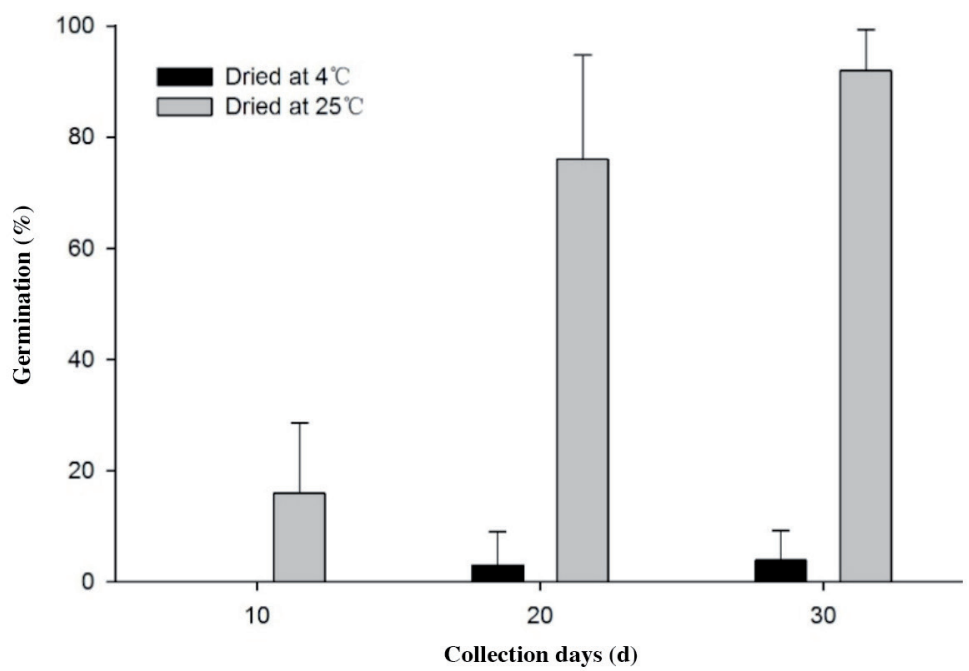




\section{Effect of temperature and light on germination}

Phleum paniculatum seed germinated at constant temperatures between 10 and $25{ }^{\circ} \mathrm{C}$, with $15{ }^{\circ} \mathrm{C}$ as the optimum temperature for germination. No seed germinated at 5 or $30^{\circ} \mathrm{C}$ constant temperatures (Figure 2). Seed germination of P. paniculatum was $87 \%$ or more under all fluctuating temperature regimes except the $30 / 20{ }^{\circ} \mathrm{C}$ where $38 \%$ of seeds germinated and the $10 / 5{ }^{\circ} \mathrm{C}$ treatment that had $0 \%$ germination (Figure 3). Our results indicate that P. paniculatum germination is adapted to the temperatures of autumn and spring where temperature typically range for 10 to $25^{\circ} \mathrm{C}$. Hot temperature $>25^{\circ} \mathrm{C}$ typically experience during the summer months and cold temperatures $<10^{\circ} \mathrm{C}$ typically experience during the winter months could inhibit seed germination.

Seed germination rate of $P$. paniculatum was $99 \pm 3.7 \%$ without light, compared with $99 \pm 3.2 \%$ with constant light, and $98 \pm 3.7 \%$ with alternative light and dark at $15 \mathrm{~d}$ after sowing, respectively (Table 1 ). These results indicate that germination of $P$. paniculatum is not inhibited nor promoted by darkness or light.

Figure 2. Effect of constant temperature on germination of Phleum paniculatum after incubation with a 12:12 h photoperiod for $15 \mathrm{~d}$. Error bars represent $95 \%$ confidence interval of the means.

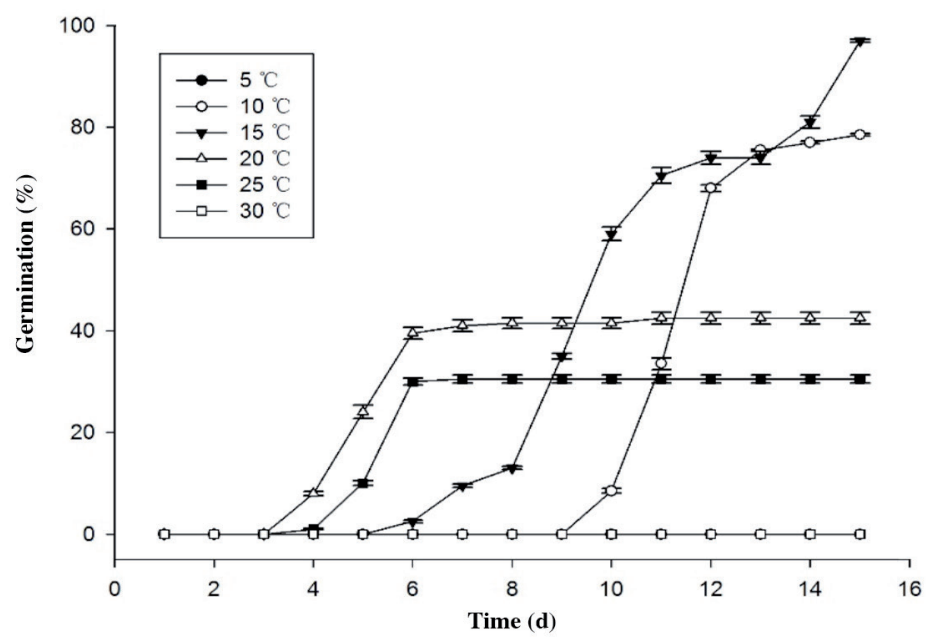

Figure 3. Effect of fluctuating temperature on germination of Phleum paniculatum after incubation with a 12:12 h photoperiod for $15 \mathrm{~d}$. Error bars represent $95 \%$ confidence interval of the means.

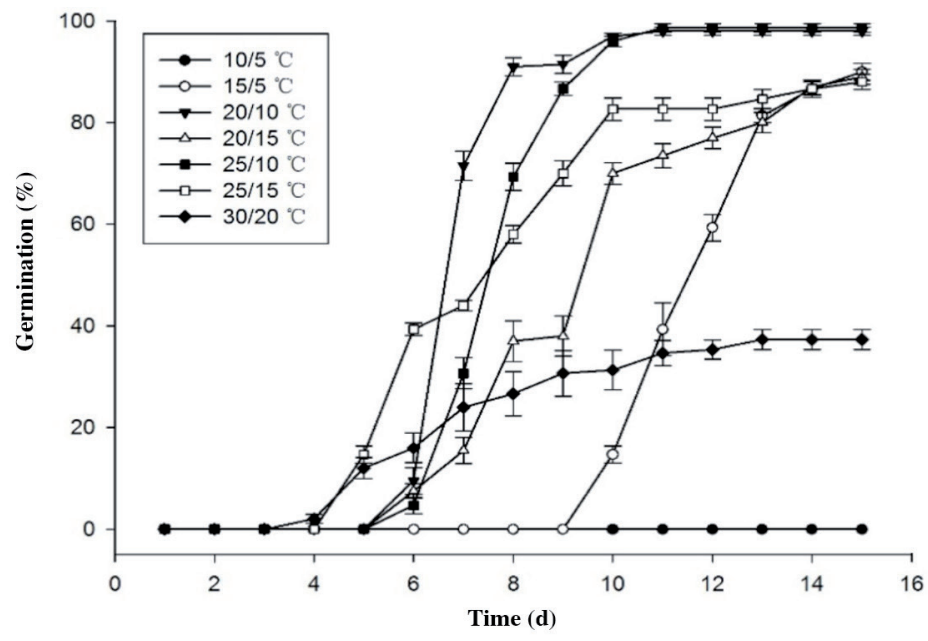


Table 1. Effect of different photoperiods of light on germination of Phleum paniculatum incubated at $20^{\circ} \mathrm{C} / 10{ }^{\circ} \mathrm{C}$ for $15 \mathrm{~d}$. Error bars represent $95 \%$ confidence interval of the means.

\begin{tabular}{cc}
\hline Photoperiod $(\mathrm{h})$ & Germination $(\%)$ \\
\hline 0 & $99 \pm 3.7 \mathrm{a}$ \\
12 & $98 \pm 3.7 \mathrm{a}$ \\
24 & $99 \pm 3.2 \mathrm{a}$ \\
\hline
\end{tabular}

Same letter represents nonsignificant difference among all treatment according to Tukey's test $(\mathrm{p} \leq 0.05)$.

\section{Effect of $\mathbf{p H}$ on germination}

Phleum paniculatum seeds germination percentages were $97.5 \pm 1.1 \%, 97.0 \pm 1.0 \%, 99.0 \pm 0.7 \%, 97.5 \pm 1.1 \%, 99.5$ $\pm 0.5 \%, 98.0 \pm 1.1 \%, 98.5 \pm 1.1 \%$ treated with $\mathrm{pH} 4,5,6,7,8,9,10$ respectively, have nonsignificant difference with distilled water $(98.5 \pm 0.7 \%$ ) at $15 \mathrm{~d}$ after sowing (Figure 4). Hence, $\mathrm{pH}$ (4 to 10) was not a limiting factor for $P$. paniculatum germination. Furthermore, with this ability, Phleum paniculatum can survive with the change of $\mathrm{pH}$ caused by long-term use of chemical fertilizers, acid rain and pollution of industrial waste (Zeng et al., 2017).

\section{Effect of osmotic stress and salinity on germination}

A logistic model used to describe P. paniculatum germination rates under different levels of water stress (Figure 5). Seed germination of $P$. paniculatum was not reduced with osmotic potentials ranging from 0 to $-0.3 \mathrm{MPa}$. Germination decreased at a water potential of $-0.35 \mathrm{MPa}(73 \pm 8 \%)$, and germination was almost completely inhibited $(3 \pm 6.1 \%)$ at a water potential of $-0.5 \mathrm{MPa}$. Our results showed that germination of P. paniculatum declined as osmotic stress increased.

A logistic model was used to describe the germination percentages obtained at different salinity levels (Figure 6). Phleum paniculatum germinated under a relatively wide range of salt concentrations ( 0 to $130 \mathrm{mM}$ ), showing a moderate adaptation to saline areas. Germination rate was greater than $62 \%$ with $\mathrm{NaCl}$ concentration less than $120 \mathrm{mM}$. With increased $\mathrm{NaCl}$ concentrations, germination dropped to $20 \pm 7.3 \%$ or $0 \%$ at 160 or $320 \mathrm{mM} \mathrm{NaCl}$, respectively. Hence, $P$. paniculatum was moderate adaptable to a relatively high salt concentration.

\section{Effect of burial depth on seedling emergence}

A logistic model was used to describe the effect of burial depth on seedling emergence of $P$. paniculatum (Figure 7). The maximum seedling emergence occurred $(97 \pm 5.5 \%)$ when seeds were placed on the surface. This emergence rate decreased slightly when seeds were buried at a depth of $0.5 \mathrm{~cm}(95.5 \pm 3 \%)$ and continued to decrease as burial depth increased with no seedlings emergence when seeds were buried at depths of $4 \mathrm{~cm}$ or more. We concluded that seedling emergence of $P$. paniculatum was quite sensitive to soil burial.

Figure 4. Effect of $\mathrm{pH}$ on germination of Phleum paniculatum incubated at $20{ }^{\circ} \mathrm{C} / 10{ }^{\circ} \mathrm{C}$ with a 12-h photoperiod for $15 \mathrm{~d}$. Error bars represent $95 \%$ confidence interval of the means.

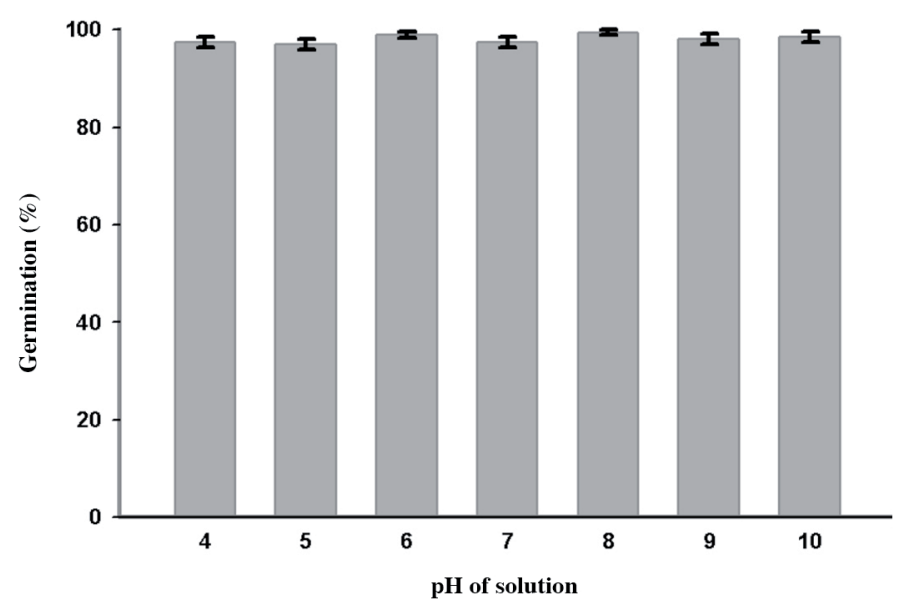


Figure 5. Effect of osmotic potential on germination of Phleum paniculatum seeds incubated at $15{ }^{\circ} \mathrm{C}$ with a 12:12 h photoperiod for $15 \mathrm{~d}$. Error bars represent $95 \%$ confidence interval of the means.

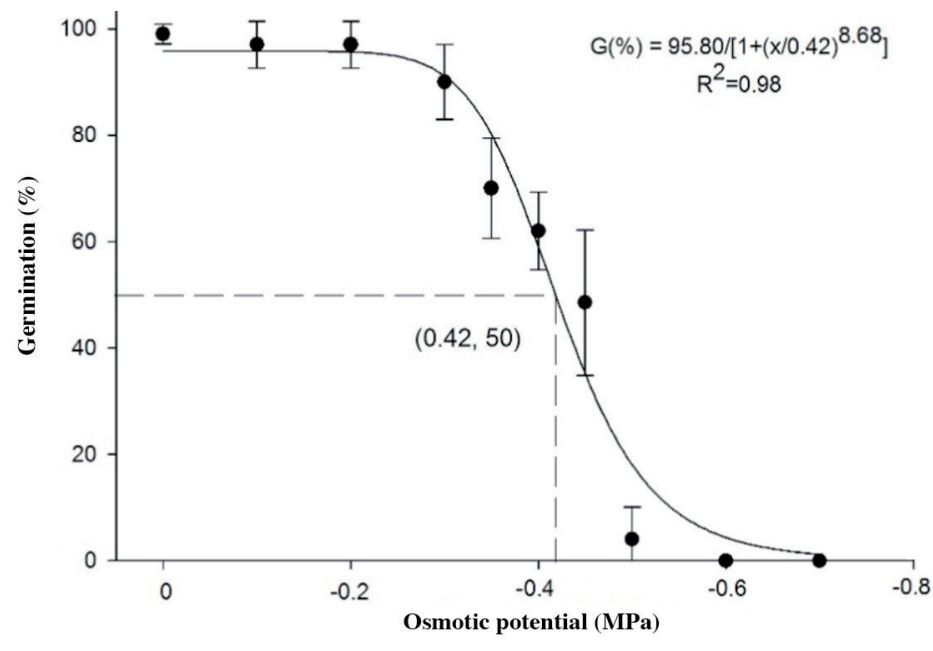

Figure 6. Effect of $\mathrm{NaCl}$ concentration on germination of Phleum paniculatum seeds incubated at $20^{\circ} \mathrm{C} / 10{ }^{\circ} \mathrm{C}$ with a 12:12 h photoperiod for $15 \mathrm{~d}$. Error bars represent $95 \%$ confidence interval of the means.

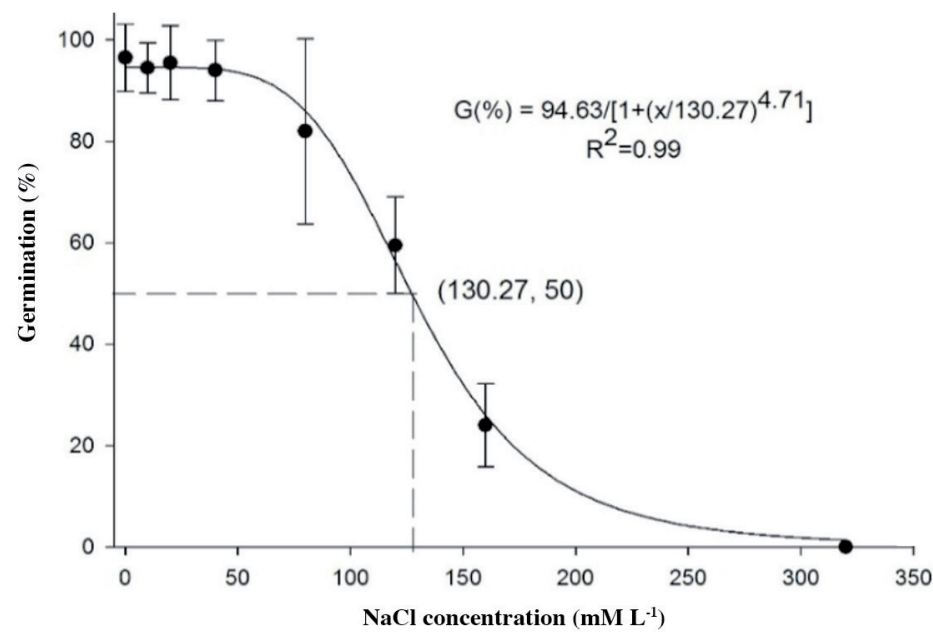

Figure 7. Effect of seed burial depth on seedling emergence of Phleum paniculatum incubated at $20^{\circ} \mathrm{C} / 10{ }^{\circ} \mathrm{C}$ with a 12:12 h photoperiod for $21 \mathrm{~d}$. Error bars represent $95 \%$ confidence interval of the means.

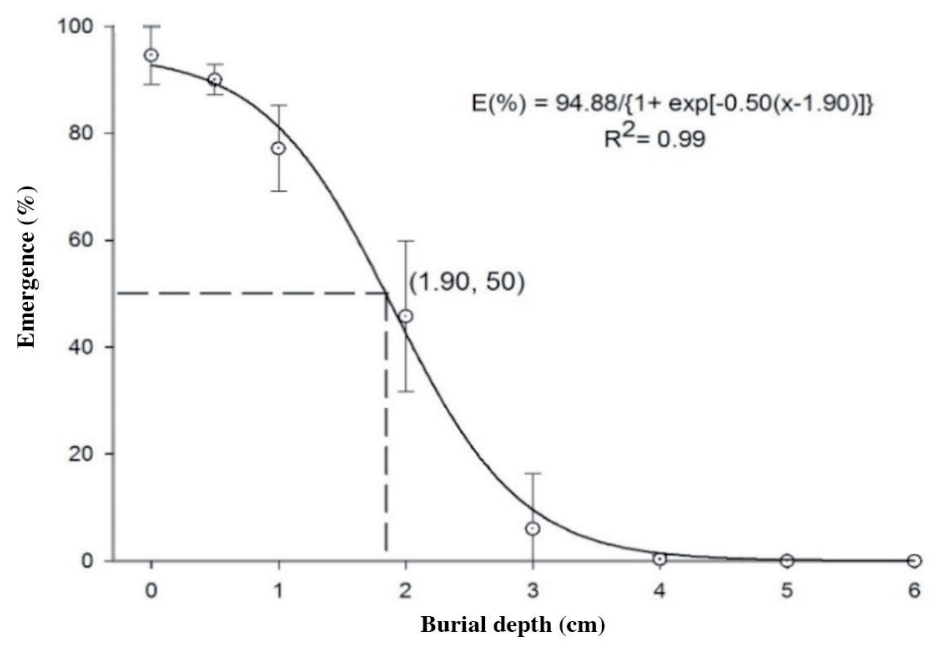




\section{DISCUSSION}

Dormancy period and adaptability to temperature of $P$. paniculatum seeds could help to protect its seedbank in wheat fields in south China. Phleum paniculatum seeds usually ripen in late-May and early-June in China, and the daily mean temperature of south China in June is above $25^{\circ} \mathrm{C}$ (National Meteorological Information Center, http://www.nmic.cn/ en/). Seed germination of P. paniculatum is adapted to temperature in autumn and spring, but not to summer $\left(>25^{\circ} \mathrm{C}\right)$ and winter $\left(<10^{\circ} \mathrm{C}\right)$. Moreover, its seeds have after ripening period of about 1-mo. These characteristics greatly benefit the maintaining of $P$. paniculatum seedbank in wheat fields during summer crop cultivation and allow P. paniculatum seeds to germinate readily when wheat is planted again.

Phleum paniculatum seeds were moderately adaptable to water potential and $\mathrm{NaCl}$ concentration. The water potential for $50 \%$ seed germination of $P$. paniculatum was $-0.42 \mathrm{MPa}$, which was higher than some other principal winter weeds in China including Polypogon fugax Nees, -0.31 MPa (Wu et al., 2015) and Galium aparine L., -0.36 MPa (Wang et al., 2016), but similar to Alopecurus japonicus Steud., $-0.42 \mathrm{MPa}$ (Wu et al., 2016); P. paniculatum appears to be more adaptable to moisture stress compared with $P$. fugax and G. aparine. Soil moisture management to limit the germination of P. paniculatum may have nonsignificant effect, as this would also impede crop germination and growth.

The $\mathrm{NaCl}$ concentration that inhibited $50 \%$ germination was calculated to be $130 \mathrm{mM}$ for $P$. paniculatum, which can be compared to wheat that has been reported to have $50 \%$ germination at $150 \mathrm{mM} \mathrm{NaCl}$ (Wang et al., 2017). This indicates that germination of $P$. paniculatum may be slightly more sensitive to high salt concentration than that of the wheat. In China, the Liao River estuary has a maximum total salt content of $1.6 \%(278.1 \mathrm{mM})$ followed by the Yellow and Yangtze River estuaries, which are $1.0 \%(173.8 \mathrm{mM})$ and $0.8 \%(139 \mathrm{mM})$, respectively (Ba and Zhao, 1997). Since $37.9 \%$ of $P$. paniculatum seeds germinated at the $140 \mathrm{mM} \mathrm{NaCl}$ concentration, the occurrence of $P$. paniculatum in Yangtze River regions may be problematic.

Deep plowing should be recommended to limit the infestation of $P$. paniculatum. Seed germination of $P$. paniculatum is not inhibited nor promoted by darkness or light, thus its seeds could germinate under soil tillage or under the dense crop canopy of wheat fields. However, the soil burial depth that inhibited $50 \%$ emergence for P. paniculatum was $1.9 \mathrm{~cm}$, which was more sensitive compared to $2.6 \mathrm{~cm}$ for Bromus japonicus Houtt. (Li et al., 2015) and $2.5 \mathrm{~cm}$ for Beckmannia syzigachne (Steud.) Fernald (Rao et al., 2008). Phleum paniculatum seed is quite small, with a thousand-seed weight of only 0.17 to $0.23 \mathrm{~g}$. Small seeds have limited nutritional storage and sustaining extensive seedling growth from germination stage to emergence may be the reason that seedling emergence of $P$. paniculatum is more sensitive to soil burial depth than other weed species (Baskin and Baskin, 1998). Many studies have reported that zero-tillage and reduced tillage often facilitate the seriousness of weed occurrence in croplands (Thomas et al., 2004; Chauhan and Johnson, 2009; Chen et al., 2017). In China, farmers either till lands to a depth of less $5 \mathrm{~cm}$ before seeding wheat or do not till the soil at all. Shallow tillage and zero tillage leave most of the weed seeds near the soil surface and may promote $P$. paniculatum infestation. Deep plowing is a possible recommendation for fields infested with P. paniculatum to bury the seed and limit its emergence.

\section{CONCLUSIONS}

Our research demonstrated that several environmental factors, including temperature, light, $\mathrm{pH}$, soil moisture, salt stress, and seed burial depth affected Phleum paniculatum germination and seedling emergence. The dormancy period and range of suitable temperature for $P$. paniculatum allow the seedbank to remain during summer crop cultivation. Light and soil $\mathrm{pH}$ had no effect on germination of P. paniculatum. Phleum paniculatum shows a moderate adaptation to salinity and water stress. No-till and shallow tillage may facilitate more $P$. paniculatum seed to germinate at the soil surface and promote infestation by this species. Proper drainage management and deep plowing are recommended to limit the detrimental effects of P. paniculatum on agricultural production. 


\section{ACKNOWLEDGEMENTS}

This research was funded by the Natural Science Foundation for Young Scientists of Jiangsu Province (BK20160724) and National Natural Science Foundation of China (31572021).

\section{REFERENCES}

Ba, F., and Zhao, Y. 1997. Soil resources of tideland in China. Chinese Journal of Soil Science 28:49-51 [In Chinese].

Baskin, C.C., and Baskin, J.M. 1998. Seeds: ecology, biogeography, and evaluation of dormancy and germination. Academic Press, San Diego, California, USA.

Chachalis, D., and Reddy, K.N. 2000. Factors affecting Campsis radicans seed germination and seedling emergence. Weed Science 48:212-216.

Chauhan, B.S., and Johnson, D.E. 2009. Influence of tillage systems on weed seedling emergence pattern in rainfed rice. Soil and Tillage Research 106:15-21.

Chen, G., Liu, Q., Zhang, Y., Li, J., and Dong, L. 2017. Comparison of weed seedbanks in different rice planting systems. Agronomy Journal 109:620-628.

Du, L., Bai, S., Li, Q., Qu, M.J., Yuan, G., Guo, W., et al. 2017. Effect of herbicide resistance endowing three ACCase mutations on seed germination and viability in American slough grass (Beckmannia syzigachne Steud. Fernald). Chilean Journal of Agricultural Research 77:142-149.

Eslami, S.V.2011. Comparative germination and emergence ecology of two populations of common lambsquarters (Chenopodium album) from Iran and Denmark. Weed Science 59:90-97.

FOC. 2006. Flora of China. Chinese Academy of Sciences, Beijing, China. Available at http://foc.eflora.cn/content. aspx?TaxonId=200025872.

Gao, X., Li, M., and Ge, Q. 2011. Biological activity of eight herbicides to eight species of major grasses in wheat fields. Acta Phytophylacica Sinica 38:557-562 [In Chinese].

Javaid, M.M., and Tanveer, A. 2014. Germination ecology of Emex spinosa and Emex australis, invasive weeds of winter crops. Weed Research 54:565-575.

Jin, P., Yang, Y., and Chen, H. 2009. The occurrence and control measures of Phleum paniculatum in wheat field at Zhouzhi county. China Agricultural Technology Extension 25:43-44 [In Chinese].

Li, Q., Tan, J., Li, W., Yuan, G., Du, L., Ma, S., et al. 2015. Effects of environmental factors on seed germination and emergence of Japanese brome (Bromus japonicus). Weed Science 63:641-646.

Michel, B.E., and Kaufmann, M.R. 1973. The osmotic potential of polyethylene glycol 6000. Plant Physiology 51:914-916.

Rao, N., Dong, L., Li, J., and Zhang, H. 2008. Influence of environmental factors on seed germination and seedling emergence of American sloughgrass (Beckmannia syzigachne). Weed Science 56:529-533.

Ruan, Y., Jin, D., and Lin, R. 1982. The host range of the wheat at rosette disease (NCMV). Acta Phytopatologica Sinica 12:21-24 [In Chinese].

Singh, M., Ramirez, A.H.M., Sharma, S.D., and Jhala, A.J. 2012. Factors affecting the germination of tall morningglory (Ipomoea purpurea). Weed Science 60:64-68.

Thomas, A.G., Derksen, D.A., Blackshaw, R.E., Van Acker, R.C., Légère, A., Watson, P.R., et al. 2004. A multistudy approach to understanding weed population shifts in medium- to long-term tillage systems. Weed Science 52:874-880.

Wang, Y., Ou, X., Zhu, Q., Li, X., Qiao, H., and Yang, X. 2017. Response of wheat seed germination to salt stress. Journal of Henan Institute of Science and Technology 45:1-8 [In Chinese].

Wang, H., Zhang, B., Dong, L., and Lou, Y. 2016. Seed germination ecology of catchweed bedstraw (Galium aparine). Weed Science 64:634-641.

Wu, X., Li, J., Xu, H., and Dong, L. 2015. Factors affecting seed germination and seedling emergence of Asia minor bluegrass (Polypogon fugax). Weed Science 63:440-447.

Wu, X., Zhang, T., Pan, L., Wang, L., Xu, H., and Dong, L. 2016. Germination requirements differ between fenoxaprop-P-ethyl resistant and susceptible Japanese foxtail (Alopecurus japonicus) biotypes. Weed Science 64:653-663.

Zeng, M., de Vries, W., Bonten, L., Zhu, Q., Hao, T., Liu X., et al. 2017. Model-based analysis of the long-term effects of fertilization management on cropland soil acidification. Environmental Science and Technology 51:3843-3851.

Zhao, J., Zhang, G., and Peng, D. 2013. Aegilops tauschii and Phleum paniculatum, two new hosts of Heterodera avenae. Acta Phytophylacica Sinica 40:379-380 [In Chinese]. 